\title{
Incidence of hepatitis $A$ and hepatitis $E$ viruses and norovirus and rotavirus in fish and shrimp samples caught from the Persian Gulf
}

\author{
[Incidência de vírus da hepatite A e hepatite E e norovírus e rotavírus em amostras de peixes e \\ camarões capturados no Golfo Pérsico] \\ M. Alipour Amroabadi ${ }^{1}$, E. Rahimi ${ }^{1 *}$, A. Shakerian ${ }^{1,2}$, H. Momtaz ${ }^{3}$ \\ ${ }^{1}$ Department of Food Hygiene, Shahrekord Branch, Islamic Azad University, Shahrekord, Iran \\ ${ }^{2}$ Research Center of Nutrition and Organic Products (RCNOP), Shahrekord Branch, \\ Islamic Azad University, Shahrekord, Iran \\ ${ }^{3}$ Department of Microbiology, Shahrekord Branch, Islamic Azad University, Shahrekord, Iran
}

\begin{abstract}
Foodborne viruses including hepatitis A virus (HAV), norovirus (NoV), rotavirus (RoV) and hepatitis $\mathrm{E}$ virus (HEV) are easily transmitted through contaminated seafoods. The current research was done to assess the incidence of RoV, NoV GI and GII,hAV and hEV in fish and shrimp samples caught from the Persian Gulf, Iran. Three-hundred and twenty fish and shrimp samples were collected. The presence of foodborne viruses were assessed by the real-time PCR. Forty-nine out of $320(15.31 \%)$ fish and shrimp samples were positive for foodborne viruses. Distribution of hAV, NoV GI and NoV GII amongst all studied samples were $0.93 \%, 5.93 \%$ and $8.43 \%$, respectively. hEV and RoV viruses were not found in studied samples. Parastromateus niger and Scomberomorus commerson fish and Penaeus monodon shrimp were the most frequently contaminated samples. Simultaneous incidence of hAV and NoV GI and hAV and NoV GII were $0.31 \%$ and $0.93 \%$, respectively. Distribution of foodborne viruses in samples collected through spring, summer, autumn and winter seasons were $14.28 \%, 9.33 \%, 11.76 \%$ and $24.44 \%$, respectively. Findings revealed that the incidence of foodborne viruses was significantly associated with seafood species and also season of sampling.
\end{abstract}

Keywords: Noroviruses, Hepatitis A virus, Seafood, Persian gulf

\section{RESUMO}

Vírus transmitidos por alimentos, incluindo hepatite $A(H A V)$, norovírus (NoV), rotavírus (RoV) e hepatite $E(H E V)$ são facilmente transmitidos através de frutos do mar contaminados. Esta pesquisa foi realizada para avaliar a incidência de RoV, NoV GI e GII, hAV e hEV em amostras de peixes e camarões capturadas no Golfo Pérsico, Irã. Foram coletadas 300 amostras de peixes e camarões. A presença de vírus transmitidos por alimentos foi avaliada por PCR em tempo real. Quarenta e nove das 320 amostras de peixes e camarões $(15,31 \%)$ foram positivas para vírus transmitidos por alimentos. A distribuição de $h A V$, NoV GI e NoV GII entre as amostras estudadas foi 0,93\%, 5,93\% e 8,43\%, respectivamente. Os vírus hEV e RoV não foram encontrados nas amostras estudadas. Os peixes Parastromateus niger e Scomberomorus commerson e o camarão Penaeus monodon foram as amostras mais frequentemente contaminadas. A incidência simultânea de $h A V$ e NoV GI, e hAV e NoV GII foi de 0,31\% e 0,93\%, respectivamente. A distribuição dos vírus transmitidos por alimentos nas amostras coletadas na primavera, verão, outono e inverno foi de 14,28\%, 9,33\%, 11,76\% e 24,44\%, respectivamente. Os resultados demonstram que a incidência de vírus transmitidos por alimentos foi significativamente associada às espécies de frutos do mar e também à época da amostragem.

Palavras-chave: norovírus, vírus da hepatite A, frutos do mar, Golfo Pérsico

Recebido em 1 de outubro de 2019

Aceito em 2 de dezembro de 2019

*Autor para correspondência (corresponding author)

E-mail: ebrahimrahimi55@yahoo.com 


\section{INTRODUCTION}

Fish and shrimp are popular amongst people of most regions of the world. However, transmission of viral contamination from the sea water and also contaminated staffs of fish and shrimp harvesting and production decreased their hygienic quality (Bosch et al., 2018). Foodborne viruses are propagated in the human intestine and secreted in stool. They are usually transmitted by the fecaloral route and also through the consumption of contaminated food and water. Norovirus (NoV), hepatitis A virus (HAV), hepatitis E virus (HEV), and rotavirus (RoV) are the most important foodborne viruses (Bosch et al., 2018). Several outbreaks of viral foodborne diseases have been reported due to the consumption of seafood harvested from sewage-contaminated waters (Hall et al., 2014; Parrón et al., 2019).

NoV belongs to the family Caliciviridae and contains positive sense single-stranded RNA. NoV is a primary pathogen that causes acute viral gastroenteritis (Hardstaff et al., 2018; Moore et al., 2015). It has a five genogroups (GI to GV). NoV GI and NoV GII are mainly associated with severe outbreaks of viral gastroenteritis (Hardstaff et al., 2018; Moore et al., 2015). NoV is the leading cause of illness from contaminated food. The virus can easily contaminate food because it is very tiny and spreads easily. It only takes a very small amount of virus to make someone sick. Major transmission routes of $\mathrm{NoV}$ are fecal-oral through contaminated food and water and person to person contact (Hardstaff et al., 2018; Moore et $a l ., 2015)$. RoV is a double-stranded RNA virus belonging to the family Reoviridae. RoV is classically divided into seven serogroups (A to $G$ ). RoV serogroups $\mathrm{A}, \mathrm{B}$, and $\mathrm{C}$ are mainly are mainly associated with severe outbreaks of viral gastroenteritis.

Group A rotavirus is a major cause of severe diarrhea in young children. It is transmitted from person to person or indirectly through contaminated food and water (Mohan et al., 2014). hAV and hEV are foodborne pathogens responsible for occurrence of hepatitis in humans. Contaminated food and water are the main sources for transmission of hAV and hEV to the human population (Melgaço et al., 2018; Moor et al., 2018; Sánchez, 2015). hAV is a singlestranded RNA virus of the family Picornaviridae. Seafood shave has also been recognized as a source of hAV (Sánchez, 2015). hEV is also a single-stranded positive-sense RNA virus of the family hepeviridae. It is responsible for occurrence of acute hepatitis due to the consumption of water and in some cases food contaminated with stool (Melgaço et al., 2018; Moor et al., 2018).

The current survey was done to evaluate role of fish and shrimp in the transmission of pathogenic viruses, and the distribution of NoV, hAV, hEV and RoV in different types of fish and shrimp samples caught from the Persian Gulf, Iran.

\section{MATERIALS AND METHODS}

The study was approved by the Ethical Council of Research of the Faculty of Veterinary Medicine, Shahrekord Branch, Islamic Azad University, Shahrekord, Iran. From May to May 2018, a total of 320 seafood samples including fish $(n=170)$ and shrimp $(n=150)$ were randomly collected from the local harbors and retail centers, Iran. Fish samples included Scomberomorus commerson (S. commerson) $(\mathrm{n}=50)$, Otolithes ruber $(O$. ruber $)$ $(\mathrm{n}=60)$ and Parastromateus niger $(P$. niger $)(\mathrm{n}=$ 60). Shrimp samples included Penaeus monodon (P. monodon) $(\mathrm{n}=50)$, Penaeus merguiensis $(P$. merguiensis $)(\mathrm{n}=50)$ and Penaeus indicus $(P$. indicus $)(\mathrm{n}=50)$.

Species identification of hard-shell samples were done by an expert professor of the field of Aquaculture. Fish and shrimp samples were caught from the Boushehr port, Persian Gulf, Iran. All samples were taken from the dorsal muscles of seafoods. All samples were placed in separate sterile plastic bags to prevent spilling and cross contamination and were immediately transported to the Food hygiene and Quality Control Research Center of the Islamic Azad University of Shahrekord in a cooler with ice packs and processed within $6 \mathrm{~h}$. All seafood samples showed normal physical characteristics including odor, color and consolidation.

A total of $1.5 \mathrm{~g}$ of the seafood samples were homogenized with $0.25 \mathrm{M}$ glycine $0.14 \mathrm{M} \mathrm{NaCl}$ buffer (pH7.5) (Sigma, St. Louis, MO, USA). The homogenate sample was transferred to a $50 \mathrm{ml}$ tube and centrifuged at $10,000 \times \mathrm{g}$ for $30 \mathrm{~min}$ at $4^{\circ} \mathrm{C}$ (Shimadzu, Japan). The primary supernatant was collected in a new tube. The pellet was resuspended in $0.25 \mathrm{M}$ Threoninee-0.14M NaCl 
buffer (pH7.5) and was then centrifuged at 10,000 $\times \mathrm{g}$ for $30 \mathrm{~min}$ at $4^{\circ} \mathrm{C}$ (Shimadzu, Japan). The secondary supernatant was then mixed with the primary supernatant.

Forty percent polyethylene glycol 6000 (PEG 6000) (Sigma, St. Louis, MO, USA) and $3 \mathrm{M} \mathrm{NaCl}$ (Amresco, Solon, OH, USA) solution was added to the collected supernatant. The mixture was precipitated at $4{ }^{\circ} \mathrm{C}$ over $3 \mathrm{~h}$. After precipitation, the pellet was dissolved in $0.2 \%$ Tween $80-50 \mathrm{mM}$ Tris-HCl (Merck, Germany), sterilized distilled water, and chloroform:isoamyl alcohol (24:1) (Sigma, St. Louis, MO,USA). The mixture was then centrifuged at $10,000 \times \mathrm{g}$ for $30 \mathrm{~min}$ at $4^{\circ} \mathrm{C}$ (Shimadzu, Japan). The supernatant was transferred to a new tube. The remaining precipitate was dissolved in sterilized distilled water and chloroform:isoamyl alcohol (24:1). The mixture was then centrifuged another time at $10,000 \times \mathrm{g}$ for $30 \mathrm{~min}$ at $4^{\circ} \mathrm{C}$ (Shimadzu, Japan), and the supernatant was then combined with the first supernatant. The mixture was precipitated with $40 \%$ PEG 6000 and $3 \mathrm{M} \mathrm{NaCl}$ solution at $4^{\circ} \mathrm{C}$ over $3 \mathrm{~h}$. The pellet was then suspended with diethylpyrocarbonate (DEPC)-treated deionized water (Sigma, St. Louis, MO, USA).

Qualitative real-time PCR was used for detection of pathogenic viruses. The pellet suspended with DEPC-treated distilled water was used for RNA extraction using the QIAamp viral RNA mini kit (Qiagen, Valencia, CA, USA). The Reverse transcription (RT) reaction mixture (Applied Biosystems, USA) consisted of sterile diethylpyrocarbonate (DEPC)-treated water, 10X PCR Buffer, 25mM dNTPs, 50 $\mu \mathrm{M}$ oligo d (T), RNase inhibitor $(20 \mathrm{U} / \mu \mathrm{l})$, murine leukemia virus (MuLV) reverse transcriptase $(50 \mathrm{U} / \mu \mathrm{l})$, and $5 \mu \mathrm{l}$ RNA template. RT was performed with an MJ mini cycler (Bio-Rad, CA, USA) with the following program: $42^{\circ} \mathrm{C}$ for $50 \mathrm{~min}, 94^{\circ} \mathrm{C}$ for $5 \mathrm{~min}$, and $4^{\circ} \mathrm{C}$ for $5 \mathrm{~min}$ (Tahk et al., 2012). Purity (A260/A280) and concentration of extracted cDNA were then checked (NanoDrop, Thermo Scientific, Waltham, MA, USA).
The truth of the cDNA was assessed on a $2 \%$ agarose gel stained with ethidium bromide $(0.5 \mu \mathrm{g} / \mathrm{mL})$ (Thermo Fisher Scientific, St. LeonRot, Germany). Two negative control reactions were performed alongside the main reactions to evaluate the accuracy of the synthesis cDNA. One PCR reaction in the presence of extracted RNA as the reaction sample and the other PCR reaction without the presence of any sample and only in the presence of water. As a rule, lack of amplification in these two reactions and amplification in the presence of cDNA indicated the validity of the synthesis. Table 1 represents the oligonucleotide primers, PCR conditions and volume of each reaction Used for detection of NoV, hAV, hEV and RoV in fish and shrimp samples.

Primers were designed to detect pathogenic viruses. First, the sequences for the desired viruses were extracted from the National Center for Biotechnology Information (NCBI) database, and then primers were designed based on the conserved regions of the different sequences for each virus using MEGA 7.0 and Oligo 7 software. PCR amplification was performed with a Thermal Cycler Dice Real-Time System (TaKaRa, Japan).

Primer application was evaluated in three different stages. In the first step, the gradient PCR reaction was performed at six different temperatures for each primer pair and the optimum binding temperature for each primer pair was selected. Secondly, PCR reactions were performed at the optimum temperature for each primer pair in the presence of positive samples (sample infected with the target virus) and negative samples (sample that did not contain the desired virus or was infected with another virus). In the third step, a standard curve was drawn for each primer pair in the presence of a positive sample. Fisher's exact test was used to analyze the correlation of virus detection rate with seafood samples. Analyses were carried out using R (Institute for Statistics and Mathematics of the WU Wien). Statistical difference was determined by $P$ value $<0.05$. 
Table 1. Oligonucleotide primers and probes used for detection of hAV, hEV, NoV GI, NoV GII and RoV in fish and shrimp samples

\begin{tabular}{|c|c|c|c|c|}
\hline $\begin{array}{l}\text { Target } \\
\text { viruses }\end{array}$ & Oligonucleotide primer & PCR volume $(25 \mu \mathrm{L})$ & PCR programs & $\begin{array}{l}\text { PCR } \\
\text { Product } \\
\text { size } \\
\text { (bp) } \\
\end{array}$ \\
\hline hAV & $\begin{array}{l}\text { F: GGTAGGCTACGGGTGAAAC } \\
\text { R: TTGCCCTAAGCACAGAGAGGT }\end{array}$ & $\begin{array}{c}\text { cDNA: } 100 \mathrm{ng} \\
\text { Primers }(10 \mathrm{pmol}) \text { : } \\
0.3 \mu \mathrm{M} \text { of eachprimer } \\
\text { 2X Master Mix Syder- } \\
\text { Green: } 12.5 \mu \mathrm{L}\end{array}$ & $\begin{array}{c}1 \text { cycle: } \\
95^{\circ} \mathrm{C}--10 \text { min. } \\
45 \text { cycle: } \\
95^{\circ} \mathrm{C}---15 \mathrm{~s} \\
58^{\circ} \mathrm{C}---35 \mathrm{~s} \\
72^{\circ} \mathrm{C}----25 \mathrm{~s}\end{array}$ & 205 \\
\hline hEV & $\begin{array}{l}\text { F: GGTGGTTTCTGGGGTGAC } \\
\text { R: AGGGGTTGGTTGGATGAA }\end{array}$ & $\begin{array}{c}\text { cDNA: } 100 \mathrm{ng} \\
\text { Primers }(10 \mathrm{pmol}) \text { : } \\
0.3 \mu \mathrm{M} \text { of eachprimer } \\
\text { 2X Master Mix Syder- } \\
\text { Green: } 12.5 \mu \mathrm{L}\end{array}$ & $\begin{array}{l}1 \text { cycle: } \\
95^{\circ} \mathrm{C}--10 \text { min. } \\
45 \text { cycle: } \\
95^{\circ} \mathrm{C}---15 \mathrm{~s} \\
55^{\circ} \mathrm{C}----35 \mathrm{~s} \\
72^{\circ} \mathrm{C}----25 \mathrm{~s}\end{array}$ & 70 \\
\hline NoV GI & $\begin{array}{c}\text { F: CGTCCTTAGACGCCATCATCATT } \\
\text { R: } \\
\text { CCAGAGGAAAGTTCAGCTTATATCC }\end{array}$ & $\begin{array}{c}\text { cDNA: } 100 \mathrm{ng} \\
\text { Primers }(10 \mathrm{pmol}) \text { : } \\
0.3 \mu \mathrm{M} \text { of eachprimer } \\
\text { 2X Master Mix Syder- } \\
\text { Green: } 12.5 \mu \mathrm{L}\end{array}$ & $\begin{array}{l}1 \text { cycle: } \\
95^{\circ} \mathrm{C}--10 \text { min. } \\
45 \text { cycle: } \\
95^{\circ} \mathrm{C}---15 \mathrm{~s} \\
58^{\circ} \mathrm{C}----35 \mathrm{~s} \\
72^{\circ} \mathrm{C}----25 \mathrm{~s}\end{array}$ & 234 \\
\hline $\begin{array}{c}\text { NoV } \\
\text { GII }\end{array}$ & $\begin{array}{c}\text { F: CTCGACGCCATCTTCATTCAC } \\
\text { R: GAAACAATGATACCACACTCCCAA }\end{array}$ & $\begin{array}{c}\text { cDNA: } 100 \mathrm{ng} \\
\text { Primers }(10 \mathrm{pmol}) \text { : } \\
0.3 \mu \mathrm{M} \text { of eachprimer } \\
\text { 2X Master Mix Syder- } \\
\text { Green: } 12.5 \mu \mathrm{L}\end{array}$ & $\begin{array}{c}1 \text { cycle: } \\
95^{\circ} \mathrm{C}--10 \text { min. } \\
45 \text { cycle: } \\
95^{\circ} \mathrm{C}---15 \mathrm{~s} \\
56^{\circ} \mathrm{C}----35 \mathrm{~s} \\
72^{\circ} \mathrm{C}----25 \mathrm{~s}\end{array}$ & 249 \\
\hline RoV & $\begin{array}{l}\text { F: CAGTGGTTGATGCTCAAGATGGA } \\
\text { R: TCATTGTAATCATATTGAATACCCA }\end{array}$ & $\begin{array}{c}\text { cDNA: } 100 \mathrm{ng} \\
\text { Primers }(10 \mathrm{pmol}) \text { : } \\
0.3 \mu \mathrm{M} \text { of eachprimer } \\
\text { 2X Master Mix Syder- } \\
\text { Green: } 12.5 \mu \mathrm{L}\end{array}$ & $\begin{array}{c}1 \text { cycle: } \\
95^{\circ} \mathrm{C}--10 \text { min. } \\
45 \text { cycle: } \\
95^{\circ} \mathrm{C}----15 \mathrm{~s} \\
56^{\circ} \mathrm{C}----35 \mathrm{~s} \\
72^{\circ} \mathrm{C}----25 \mathrm{~s}\end{array}$ & 131 \\
\hline
\end{tabular}

\section{RESULTS}

A total of 320 seafood samples were studied for presence of NoV, hAV, hEV and RoV. Applied method failed to amplify hEV and RoV in studied fish and shrimp samples. Real-time PCR amplification curves are shown in Figure 1. Additionally, real-time PCR melting curves are shown in Figure 2.

Table 2 represents the distribution of NoV, hAV, $\mathrm{hEV}$ and RoV in fish and shrimp samples. Fortynine out of $320(15.31 \%)$ fish and shrimp samples were positive for viruses. Incidence of hAV, NoV GI and NoV GII amongst all studied samples was $0.93 \%, 5.93 \%$ and $8.43 \%$, respectively. Applied method failed to detect hEV and RoV in studied samples. $P$. niger had the highest incidence of NoV GII $(8.33 \%)$, while S. commerson had the highest incidence of hAV (2\%) and NoV GI (6\%) amongst all studied fish species. $P$. monodon had the highest incidence of hAV $(2 \%)$, NoV GI $(12 \%)$ and NoV GII (18\%) amongst all studied shrimp species. Simultaneous incidence of hAV and NoV GI was $0.31 \%$. Simultaneous incidence of hAV and NoV GII was $0.93 \%$. Statistically significant difference was found between type of samples and incidence of pathogenic viruses $(\mathrm{P}<0.05)$.

Table 3 represents the seasonal distribution of hAV, NoV GI and NoV GII in fish and shrimp samples. Incidence of pathogenic viruses in all studied samples collected through spring, summer, autumn and winter seasons was $14.28 \%$, $9.33 \%, 11.76 \%$ and $24.44 \%$, respectively. Furthermore, incidence of pathogenic viruses in raw fish samples collected through spring, summer, autumn and winter seasons was $12.50 \%$, $6 \%, 6 \%$ and 20\%, respectively. Moreover, incidence of pathogenic viruses in raw shrimp 
samples collected through spring, summer, autumn and winter seasons was $16.66 \%, 11.42 \%$, $20 \%$ and $28 \%$, respectively. Statistically significant differences were found between season of sampling and incidence of pathogenic viruses $(\mathrm{P}<0.05)$.
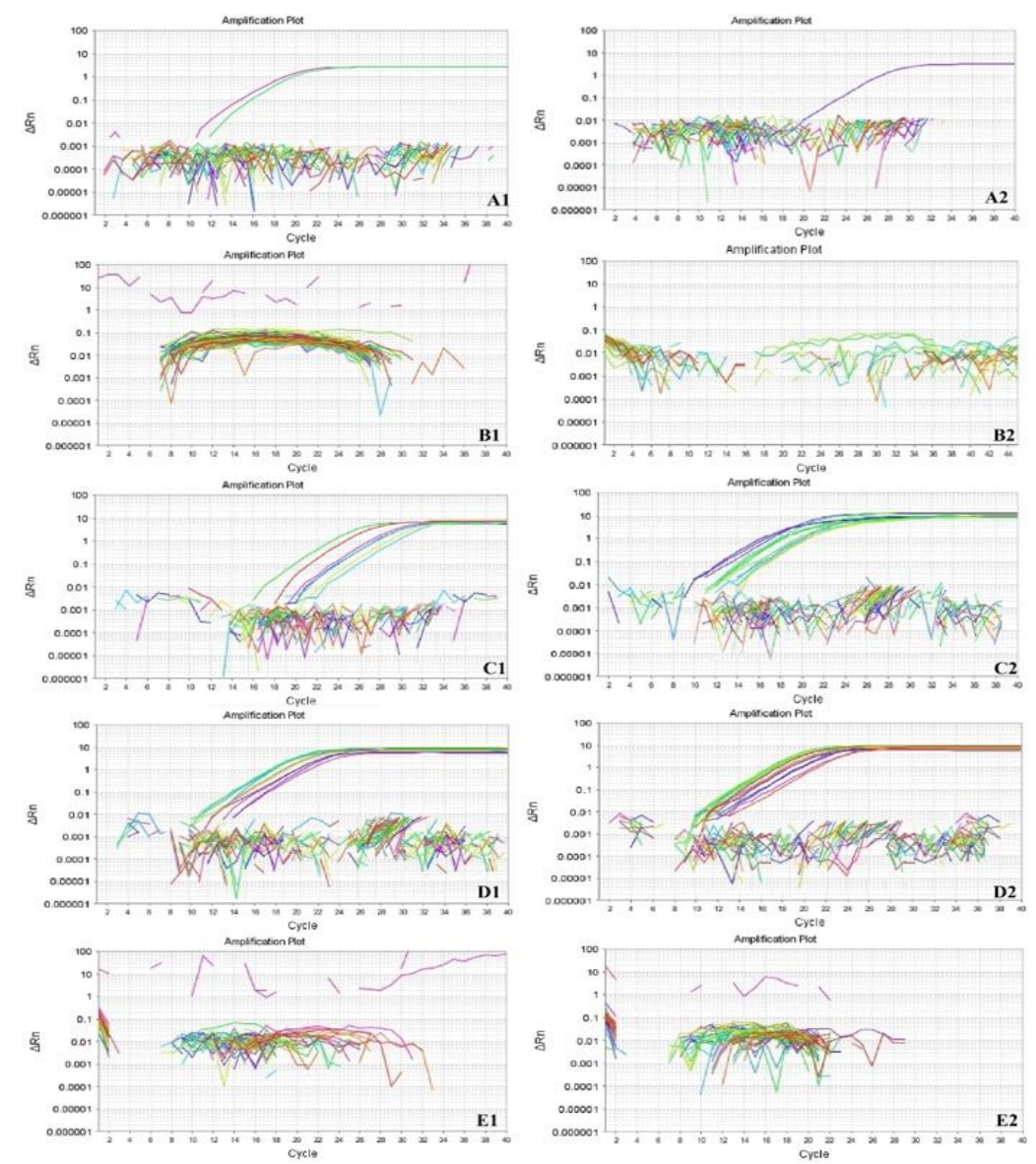

Figure 1. Samples of amplification cycles of studied pathogenic viruses in fish and shrimp samples. A1:hAV in fish samples, A2:hAV in shrimp samples, B1:hEV in fish samples, B2:hEV in shrimp samples, C1: NoV GI in fish samples, C2: NoV GI in shrimp samples, D1: NoV GII in fish samples, D2: NoV GII in shrimp samples, E1: RoV in fish samples, E2: RoV in shrimp samples.

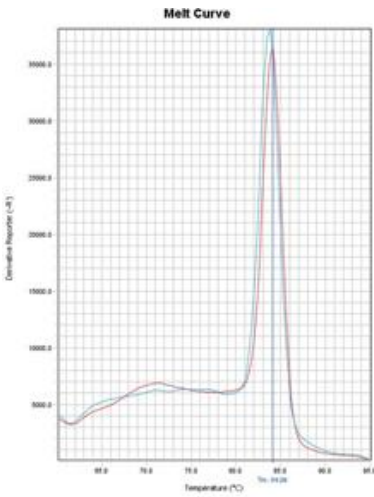

HAV

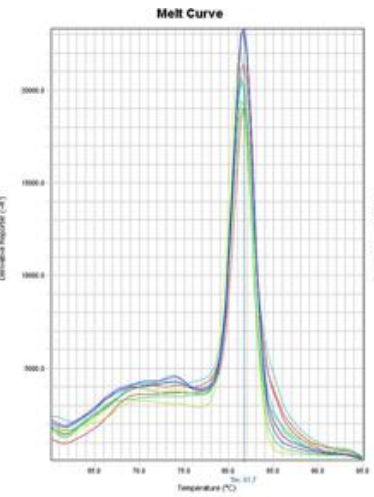

NOV GI

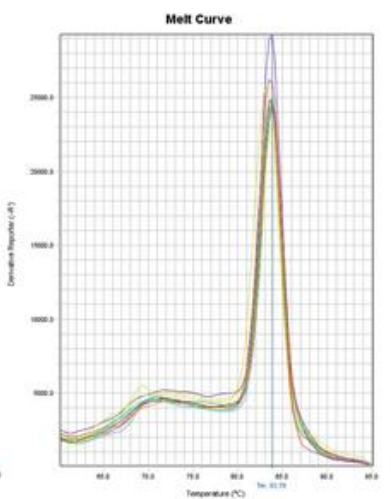

NOV GII

Figure 2. Samples of melting cycles of studied pathogenic viruses in fish and shrimp samples. 
Table 2. Distribution of hAV, hEV, NoV GI, NoV GII and RoV in different species of fish and shrimp samples

\begin{tabular}{|c|c|c|c|c|c|c|c|c|c|}
\hline \multirow{2}{*}{\multicolumn{2}{|c|}{ Type of samples }} & \multirow{2}{*}{$\begin{array}{c}\text { N. } \\
\text { samples } \\
\text { collected }\end{array}$} & \multicolumn{7}{|c|}{ N. samples positive for viruses (\%) } \\
\hline & & & HAV & HEV & NoV GI & NoV GII & RoV & $\begin{array}{l}\mathrm{HAV}+ \\
\text { NoV GI }\end{array}$ & $\begin{array}{c}\text { HAV + } \\
\text { NoV GII }\end{array}$ \\
\hline \multirow{4}{*}{ Fish } & S. commerson & 50 & $1(2)$ & - & $3(6)$ & $3(6)$ & - & - & $1(2)$ \\
\hline & O. ruber & 60 & - & - & $1(1.66)$ & $2(3.33)$ & - & - & - \\
\hline & $P$. niger & 60 & $1(1.66)$ & - & $3(5)$ & $5(8.33)$ & - & $1(1.66)$ & $1(1.66)$ \\
\hline & Total & 170 & $2(1.17)$ & - & $7(4.11)$ & $10(5.88)$ & - & $1(0.58)$ & $2(1.17)$ \\
\hline \multirow{4}{*}{ Shrimp } & P. monodon & 50 & 1(2) & - & $6(12)$ & $9(18)$ & - & 1(2) & 1(2) \\
\hline & P. merguiensis & 50 & - & - & $3(6)$ & $3(6)$ & - & - & - \\
\hline & P. indicus & 50 & - & - & $3(6)$ & $5(10)$ & - & - & - \\
\hline & Total & 150 & $1(0.66)$ & - & $12(8.00)$ & $17(11.33)$ & - & - & $1(0.66)$ \\
\hline Total & & 320 & $3(0.93)$ & - & $19(5.93)$ & $27(8.43)$ & - & $1(0.31)$ & $3(0.93)$ \\
\hline
\end{tabular}

Table 3. Seasonal distribution of hepatitis A and hepatitis E viruses and noroviruses and rotavirus in fish and shrimp samples

\begin{tabular}{lcccccccc}
\hline Types of samples (N & \multicolumn{3}{c}{ N samples collected in each season } & \multicolumn{3}{c}{ N (\%) samples positive in each season } \\
\cline { 2 - 8 } \multicolumn{1}{c}{ positive samples) } & Spring & Summer & Autumn & Winter & Spring & Summer & Autumn & Winter \\
\hline Fish (19) & 40 & 40 & 50 & 40 & $5(12.50)^{*}$ & $3(6)$ & $3(6)$ & $8(20)$ \\
Shrimp (30) & 30 & 35 & 35 & 50 & $5(16.66)$ & $4(11.42)$ & $7(20)$ & $14(28)$ \\
Total (49) & 70 & 75 & 85 & 90 & $10(14.28)$ & $7(9.33)$ & $10(11.76)$ & $22(24.44)$ \\
\hline
\end{tabular}

*Positive samples were obtained from all detected viruses.

\section{DISCUSSION}

To our knowledge, this is the first report of the incidence of foodborne viruses in fish and shrimp samples caught from the Persian Gulf, Iran. Compared with the detection rates of viruses, NoV GI (5.93\%) and NoV GII (8.43\%) were the significantly prevalent pathogens in fish and shrimp samples caught from the Persian Gulf, Iran. Incidence of hAV (0.93\%) was entirely low amongst the studied samples. High incidence of NoV GII was also reported in different previously published investigations conducted on South Korea (Park et al., 2012) and Italy (La Bella et al., 2017). Seo et al. (2014) reported that the incidence of NoV GI, NoV GII and hAV amongst the shellfish samples collected from local market in the Kyounggi area, South Korea were $5.90 \%, 21.70 \%$ and $0.70 \%$, respectively.

The used TaqMan Probe Real-Time PCR failed to detect hEV and RoV in studied samples which was similar to our findings. Fusco et al. (2019) reported that the incidence ofhAV, NoV GI, NoV GII, RoV and hEV amongst the shellfish samples collected from the gulf of Naples, Italy from 2015 to 2017 were $8.90 \%, 10.80 \%, 39.70 \%$, $9.00 \%$ and $0 \%$, respectively which showed the higher incidence of foodborne viruses than our findings. Mesquita et al. (2011) reported that 34 $(69.00 \%)$ out of the 49 shellfish batches collected from the Portugal was contaminated by at least one of the NoV, hAV and EV. They showed that simultaneous incidence of NoV/HAV, NoV/enterovirus (EV) and EV/HAV, was $6.00 \%, 8.00 \%$ and $8.00 \%$, respectively.

Purpari et al. (2019) reported that the incidence of hAV, NoV GI, NoV GII, RoV and hEV in seafood samples collected from Italy were $13.00 \%, 10.20 \%, 5.60 \%, 0 \%$ and $0.90 \%$, respectively. High contamination rate of $\mathrm{NoV}$ in seafood was reported in $45.00 \%$ and $54.00 \%$ in Spain and in $38.00 \%$ and $37.00 \%$ in Thailand and Portugal, respectively (Diez-Valcarce et al., 2012; Kittigul et al., 2011; Mesquita et al., 2011; Vilariño et al., 2009).

Among all 320 seafood samples, hAV was detected in only 2 fish $(1.17 \%)$ and one shrimp $(0.66 \%)$ sample. Our finding was very close to the incidence of hAV reported in the United Kingdom, South Korea and Japan (Formiga-Cruz et al., 2002; Hansman et al., 2008; Seo et al., 2014). Higher incidence rate of hAV in seafood samples (22.00-36.00\%) was reported Brazil, Portugal and Italy (Coelho et al., 2003; Croci et al., 2000; Mesquita et al., 2011). Because hAV was detected in only $0.93 \%$ of fish and shrimp samples, it has been suggested that the possibility of transmission of hAV through the consumption of fish and shrimp in Iran may be very low.

Fascinatingly, hEV and RoV have not been detected in fish and shrimp samples collected from the Persian Gulf, Iran. hEV is a significant 
infection amongst the European countries, and over the last 10 years more than 21,000 acute clinical cases with 28 fatalities have been notified with an overall 10 -fold increase in reported $\mathrm{hEV}$ cases; the majority $(80 \%)$ of cases were reported from France, Germany and the UK (Hazards et al., 2017). However, as infection in humans is not notifiable in all Member States, and surveillance differs between countries, the number of reported cases is not comparable and the true number of cases would probably be higher (Hazards et al., 2017).

Similar to findings of the present study, hEV contamination was not found in seafood samples in Finland, South Korea and Thailand (DiezValcarce et al., 2012; Seo et al., 2014). The applied method failed to detect hEV and RoV in studied samples. The probable reason for this finding is the absence of these two pathogenic viruses in a sea water and also amongst the studied samples. Additionally, staffs of the fishing centers were negative for these two pathogenic viruses. Differences in the diet of studied samples, distance of living from the beach, depth of their lives and finally their route of maintenance are probable factors affecting differences in the incidence of different viruses in diverse samples.

RoV has been documented as a scarce reason for causing seafood-associated disease. This may be due to low survival in the marine environment or poor diagnostics. Rotaviruses is often associated with infant diarrhea but may not be considered in adults. Furthermore, adults may excrete only low quantities of the virus which could be missed under the electron microscope. Moreover, the concentration of RoV shedded in stool samples is relatively low $\left(3 \times 10^{5}-5 \times 10^{11}\right.$ viral particles/g of stool) (Mohan et al., 2014).

Reversely, the infective dose of RoV is relatively low (10-100 virus particles) which makes it a significant foodborne pathogen (Mohan et al., 2014). RoV can contaminate seafood growing areas from a number of sources including septic tank leakages, boat discharges, overflows and spills from sewage treatment plants seepage from sewage reticulation networks and accidental contamination after heavy rainfall (Mohan et al., 2014). Similar to findings of the present study, Vilariño et al. (2009) reported that RoV had the least incidence amongst all foodborne viruses detected in seafood samples caught from the Spain. Unlike the findings of the present investigation, Hansman et al. (2008) reported that the incidence of RoV in seafood samples caught from Japan was $42.00 \%$. Mohan et al. (2014) reported that the incidence of Rov in seafood samples collected from India was $2.50 \%$. Similar findings were found in a survey conducted in China where in $3.33 \%$ of the seafood samples were positive for RoV (Kou et al., 2005). Incidence as high as $52.00 \%$ has been reported in a study conducted in France (Le Guyader et al., 2000).

Findings of the present study showed higher contamination rate of foodborne viruses in fish and shrimp samples collected through the winter season. In numerous investigations, seasonal variation of foodborne viruses has been clarified by the fact that viruses are less effectively removed from seafoods in winter and could survive better in colder seasons than in warmer (La Bella et al., 2017). Many researches have reported a seasonal distribution of NoV detection in seafood samples mostly in the colder months (Le Guyader et al., 2000; Lowther et al., 2012; Suffredini et al., 2012), thus suggesting seasonality for these virus infections. NoV illnesses related to seafood consumption present a seasonal pattern, generally showing a peak incidence during the wintertime.

This seasonality could be attributed to several factors, including increased stability of viruses at low water temperature, reduced solar inactivation, and selective bioaccumulation of these pathogens by seafoods (Suffredini et al., 2012). Similarly, Seo et al. (2014) reported that the incidence of NoV GI, NoV GII and hAV amongst the seafood samples collected through summer and winter seasons were $6.80 \%$ and $5.60 \%, 13.60 \%$ and $25.00 \%$ and $0.00 \%$ and $0.90 \%$, respectively. Furthermore, Fusco et al. (2019) stated that hAV-positive seafood samples displayed a seasonal pattern, with samples only testing positive between December and April (colder months).

However, further investigations are required to find more epidemiological properties of foodborne viruses in seafood samples. High incidence of diverse foodborne pathogens other than pathogenic viruses has been stated in different kinds of food samples, particularly 
foods with animal origins (Abdolmaleki et al., 2019a, 2019b; Atapoor et al., 2014; Dehkordi 2011a, 2011b; Dehkordi et al., 2012a, 2012b, 2012c;, 2013; Dehkordi et al., 2014a, 2014b; Dehkordi and Rafsanjani 2013; Ghorbani et al., 2016; Hasanpour Dehkordi et al., 2017; Hemmatinezhad et al., 2015; Mashak et al., 2020a, 2020b; Momtaz et al., 2012, 2013; Mousavi et al., 2014; Momtaz et al., 2015; Nejat et al., 2015; Rahi et al., 2020; Rahimi et al., 2014; Ranjbar et al., 2017, 2018a; 2018b, 2018c, 2019a, 2019b, 2020; Safarpoor Dehkordi et al., 2013, 2017, 2018). Thus, principles of food safety should be observed to decrease the outbreaks of several foodborne diseases.

\section{CONCLUSIONS}

NoV, particularly NoV GII is the most prevalent foodborne virus in fish and shrimp samples caught from the Persian Gulf, Iran. In keeping with this, hAV and NoV GI should be considered as other important foodborne viruses in the present study. Findings revealed that the incidence of foodborne viruses was significantly associated with seafood species and also seasonal variations. $P$. niger and S. commerson fish and $P$. monodon shrimp were the most commonly contaminated species. Higher contamination rate was detected in winter season. Although the viability of foodborne viruses could not be confirmed due to the limitation of real-time RTPCR and the lack of cultivation techniques, monitoring of foodborne viruses in fish and shrimp samples may contribute to the prevention of viral food poisoning and the promotion of public health.

\section{REFERENCES}

\begin{abstract}
ABDOLMALEKI, Z.; MASHAK, Z.; SAFARPOOR DEHKORDI, F. Phenotypic and genotypic characterization of antibiotic resistance in the methicillinresistant Staphylococcus aureus strains isolated from hospital cockroaches. Antimicrob Res Infect Control., v.8, p.1-4, 2019a.
\end{abstract}

ABDOLMALEKI, Z.; MASHAK, Z.; SAFARPOOR DEHKORDI, F. Molecular and virulence characteristics of methicillin-resistant Staphylococcus aureus bacteria recovered from hospital cockroaches. Jundishapur. J Microbiol., v.12, p.e98564, 2019b.

ATAPOOR, S.; DEHKORDI, F.S.; RAHIMI, E. Detection of Helicobacter pylori in various types of vegetables and salads. Jundishapur. J Microbiol., v.7, p.e10013, 2014.
BOSCH, A.; GKOGKA, E.; LE GUYADER, F.S. et al. Foodborne viruses: detection, risk assessment, and control options in food processing. Int. J. Food. Microbiol., v.285, p.110-128, 2018.

COELHO, C.; HEINERT, A.; SIMÕES, C.; BARARDI, C. Hepatitis a virus detection in oysters (Crassostrea gigas) in Santa Catarina State, Brazil, by reverse transcription-polymerase chain reaction. J. Food. Prot., v.66, p.507-511, 2003.

CROCI, L.; MEDICI, D.; SCALFARO, C. et al. Determination of enteroviruses, hepatitis a virus, Bacteriophages and Escherichia Coli in Adriatic sea mussels. J. Appl. Microbiol., v.88, p.293-298, 2000.

DEHKORDI, F.S. Prevalence study of bovine viral diarrhea virus by evaluation of antigen capture elisa and rt-pcr assay in bovine, ovine, caprine, buffalo and camel aborted fetuses in Iran. AMB Express., v.1, p.1-6, 2011a.

DEHKORDI, F.S. Prevalence study of Coxiella burnetii in aborted ovine and caprine fetuses by evaluation of nested and real-time PCR assays. Am J Anim Vet Sci., v.6, p.180-186, 2011b.

DEHKORDI, F.S.; HAGHIGHI, N.; MOMTAZ, H.; RAFSANJANI, M.S.; MOMENI, M. Conventional vs real-time PCR for detection of bovine herpes virus type 1 in aborted bovine, buffalo and camel foetuses. Bulgar. J. Vet. Med., v.16, p.102-111, 2013.

DEHKORDI, F.S.; KHAMESIPOUR, F.; MOMENI, M. Brucella abortus and Brucella melitensis in Iranian bovine and buffalo semen samples: The first clinical trial on seasonal, Senile and geographical distributionUsing culture, conventional and real-time polymerase chain reaction assays. Kafkas. Univ. Vet. Fak. Dergisi, v.20, p.821-828, 2014a.

DEHKORDI, F.S.; MOMTAZ, H.; DOOSTI, A. Application of Real-Time PCR for detection of Aspergillus species in aborted ruminant foetuses. Bulg $J$ Vet Med., v.15, p.30-36, 2012a.

DEHKORDI, F.S.; PARSAEI, P.; SABERIAN, S. et al. Prevalence study of Theileria annulata by comparison of four diagnostic techniques in southwest Iran. Bulgar. J. Vet. Med., v.15, p.123-130, 2012a.

DEHKORDI, F.S.; RAFSANJANI, M.S. Prevalence study of Coxiella burnetii in aborted fetuses of small ruminants in various partum and seasons in Iran. Afr $J$ Microbiol Res., v.6, p.5594-5600, 2012 b.

DEHKORDI. F.S.; SABERIAN. S.; MOMTAZ, H. Detection and segregation of Brucella abortus and Brucella melitensis in aborted bovine, ovine, caprine, buffaloes and camelid fetuses by application of conventional and real-time polymerase chain reaction. Thai J Vet Med., v.42, p.13-20, 2012a.

DEHKORDI, F.S.; VALIZADEH, Y.; BIRGANI, T.A.; DEHKORDI, K.G. Prevalence Study of Brucella melitensis and Brucella abortus in cow's milkUsing dot enzyme linked immuno sorbent assay and duplex polymerase chain reaction. J. Pure Appl. Microbiol., v.8; p.1065-1069, 2014b. 
DIEZ-VALCARCE, M.; KOKKINOS, P.; SÖDERBERG, K. et al. Occurrence ofhuman enteric viruses in commercial mussels at retail level in three European Countries. Food. Environ. Virol., v.4, p.73-80, 2012.

FORMIGA-CRUZ, M.; TOFINO-QUESADA， G.; BOFILL-MAS, S. et al. Distribution ofhuman virus contamination in Shellfishfrom different growing areas in Greece, Spain, Sweden, and the United Kingdom. Appl. Environ. Microbiol., v.68, p.5990-5998, 2002.

FUSCO, G.; ANASTASIO, A.; KINGSLEY, D.H. et al. Detection ofhepatitis a virus and other enteric viruses in ShellfishCollected in the Gulf of Naples, Italy. Int. J. Environ. Publ. Health, v.16, p.2588, 2019.

GHORBANI, F.; GHEISARI, E.; DEHKORDI, F.S. Genotyping of vacA alleles ofhelicobacter pylori strains recovered from some Iranian food items. Trop. J. Pharm. Res., v.15, p.1631-1636, 2016.

HALL, A.J.; WIKSWO, M.E.; PRINGLE, K.; GOULD, L.H.; PARASHAR,U.D. Vital signs: foodborne norovirus outbreaks-United States, 2009-2012. MMWR. Morb. Mortal. Wkly Rep., v.63, p.491, 2014.

HANSMAN, G.S.; OKA, T.; LI, T.C. et al. Detection ofhuman enteric viruses in Japanese Clams. J. Food. Prot., v.71, p.1689-1695, 2008.

HARDSTAFF, J.L.; CLOUGH, H.E.; LUTJE, V. et al. Foodborne and food-handler norovirus outbreaks: a systematic review. Foodborne Pathog. Dis., v.15, p.589597, 2018

HASANPOUR DEHKORDI, A.; KHAJI, L.; SAKHAEI SHAHREZA, M.H.; MASHAK, Z.; SAFARPOOR DEHKORDI, F.; SAFAEE, Y.; HOSSEINZADEH, A.; ALAVI, I.; GHASEMI, E.; RABIEI-FARADONBEH, M. One-year prevalence of antimicrobial susceptibility pattern of methicillin-resistant Staphylococcus aureus recovered from raw meat. Trop Biomed., v.34, p.396-404, 2017.

HAZARDS, E.P.O.B.; RICCI, A.; ALLENDE, A. et al. Public health risks associated withhepatitis E Virus (Hev) as a Food-Borne Pathogen. EFSA. J., v.15, p.e04886, 2017.

HEMMATINEZHAD, B.; KHAMESIPOUR, F.; MOHAMMADI, M.; SAFARPOOR DEHKORDI, F.; MASHAK, Z. Microbiological investigation of $\mathrm{O}$ serogroups, virulence factors and antimicrobial resistance properties of shiga toxin-producing Escherichia coli isolated from ostrich, turkey and quail meats. J. Food. Saf., v.35, p.491-500, 2015.

KITTIGUL, L.; POMBUBPA, K.; SUKONTHALUX, S.; RATTANATHAM, T.; UTRARACHKIJ, F. Noroviruses in oysters from local markets and oyster farms in Southern Thailand. Southeast. Asian J. Trop. Med. Public Health, v.42, p.105e113, 2011.

KOU, X.; WU, Q.; ZHANG, J.; FAN,H. Study on rotavirus detection withsingle-tube seminested rt-pcr method in shellfish. Acta. Microbiol. Sinica, v.45, p.401404, 2005
LA BELLA, G.; MARTELLA, V.; BASANISI, M. et al. Food-Borne viruses in shellfish: investigation on norovirus and hav presence in apulia (Se Italy). Food Environ. Virol., v.9, p.179-186, 2017.

LE GUYADER, F.; HAUGARREAU, L.; MIOSSEC, L.; DUBOIS, E.; POMMEPUY, M. Three-year study to assesshuman enteric viruses in shellfish. Appl. Environ. Microbiol., v.66, p.3241-3248, 2000.

LOWTHER, J.A.; GUSTAR, N.E.; POWELL, A.L.;HARTNELL, R.E.; LEES, D.N. Two-year systematic study to assess norovirus contamination in oysters from commercial harvesting areas in the United Kingdom. Appl. Environ. Microbiol., v.78, p.5812-5817, 2012.

MASHAK, Z.; BANISHARIF, F.; BANISHARIF, G.; REZA POURIAN, M.; ESKANDARI, S.; SEIF, A.; SAFARPOOR DEHKORDI, F.; ALAVI, I. Prevalence of listeria species and serotyping of Listeria monocytogenes bacteria isolated from seafood samples. Egypt J Vet Sci., v. 52 , p. $1-9,2020$ b.

MASHAK, Z.; JAFARIASKARI, S.; ALAVI, I.; SHAHREZA, M.S.; DEHKORDI, F.S. Phenotypic and genotypic assessment of antibiotic resistance and genotyping of vacA, cagA, iceA, oipA, cagE, and babA2 alleles of Helicobacter pylori bacteria isolated from raw meat. Infect Drug Res., v.13, p. 257, 2020a.

MELGAÇO, J.G.; GARDINALI, N.R.; MELLO, V.D.M.D. et al. Hepatitis E: update on prevention and control. Biomed. Res. Int., v.2018, p.5769201, 2018.

MESQUITA, J.R.; VAZ, L.; CERQUEIRA, S. et al. Norovirus, hepatitis a virus and enterovirus presence in shellfishfromhighqualityharvesting areas in Portugal. Food Microbiol., v.28, p.936-941, 2011.

MOHAN, V.; RAWAT, S.; LOKESH, K. et al. Prevalence of rotavirus in shellfish from Southern Kerala. Vet. World, v.7, p.821-824, 2014.

MOMTAZ, H.; SAFARPOOR DEHKORDI, F.; TAKTAZ, T.; REZVANI, A.; YARALI, S. Shiga toxinproducing Escherichia coli isolated from bovine mastitic milk: serogroups, virulence factors, and antibiotic resistance properties. Sci. World J., v.2012, p.618709, 2012.

MOMTAZ,H.; RAHIMIAN, M.D.; SAFARPOOR DEHKORDI, F. Identification and characterization of Yersinia enterocolitica isolated from raw chicken meat based on molecular and biological techniques. J. Appl. Poult. Res., v.22, p.137-145, 2013.

MOOR, D.; LINIGER, M.; BAUMGARTNER, A.; FELLEISEN, R. Screening of ready-to-eat meat products forhepatitis E virus in Switzerland. Food. Environ. Virol., v.10, p.263-271, 2018.

MOORE, M.D.; GOULTER, R.M.; JAYKUS, L.A. Human norovirus as a Foodborne Pathogen: challenges and developments. Ann. Rev. Food. Sci. Technol., v.6, p.411-433, 2015. 
MOUSAVI, S.; DEHKORDI, F.S.; RAHIMI, E. Virulence factors and antibiotic resistance ofhelicobacter pylori isolated from raw milk andUnpasteurized dairy products in Iran. J. Venom. Anim. Toxins Incl. Trop. Dis., v.20, p.51, 2014.

NEJAT, S.; MOMTAZ, H.; YADEGARI, M.; NEJAT, S.; SAFARPOUR DEHKORDI, F. KHAMESIPOUR, F. Seasonal, geographical, age and breed distributions of equine viral arteritis in Iran. Kafkas Univ Vet Fak Derg., v. 21 , p. 111-116, 2015.

PARK, K.; YEO, S.; JEONG, H. et al. Updates on the genetic variations of norovirus in sporadic gastroenteritis in Chungnam Korea, 2009-2010. Virol. J., v.9, p.29, 2012.

PARRÓN, I.; ÁLVAREZ, J.; JANÉ, M. et al. A Foodborne norovirus outbreak in a nursing home and spread to staff and their household contacts. Epidemiol. Infect., v.147, e225, 2019.

PURPARI, G.; MACALUSO, G.; DI BELLA, S. et al. Molecular characterization ofhuman enteric viruses in food, water samples, and surface swabs in Sicily. Int. $J$. Infect. Dis., v.80, p.66-72, 2019.

RAHI, A.; KAZEMEINI, H.; JAFARIASKARI, S.; SEIF, A.; HOSSEINI, S.; DEHKORDI, F.S. Genotypic and Phenotypic-Based Assessment of antibiotic resistance and profile of staphylococcal cassette chromosome mec in the methicillin-resistant Staphylococcus aureus recovered from raw milk. Infect Drug Res., v.13, p.273, 2020.

RAHIMI, E.; YAZDANPOUR, S.; DEHKORDI, F.S. Detection of toxoplasma gondii antibodies in various poultry meat samples using enzyme linked immuno sorbent assay and its confirmation by polymerase chain reaction. J. Pure Appl. Microbiol., V.8, p.421-427, 2014.

RANJBAR, R.; DEHKORDI, F.S.; HEIAT, M. The frequency of resistance genes in Salmonella enteritidis strains isolated from cattle. Iran J Publ Health., v.49, p.968-974, 2020.

RANJBAR, R.; FARSANI, F.Y.; DEHKORDI, F.S. Phenotypic analysis of antibiotic resistance and genotypic study of the vacA, cagA, iceA, oipA and babA genotypes of the Helicobacter pylori strains isolated from raw milk. Antimicrob Res Infect Control., v.7, p.115, 2018a.

RANJBAR, R.; MASOUDIMANESH, M.; DEHKORDI, F.S.; JONAIDI-JAFARI, N.; RAHIMI, E. Shiga (Vero)toxin producing Escherichia coli isolated from the hospital foods; virulence factors, o-serogroups and antimicrobial resistance properties. Antimicrob. Res. Infect. Control., v.6, p.4, 2017.
RANJBAR, R.; SAFARPOOR DEHKORDI, F.; SAKHAEI SHAHREZA, M.H.; RAHIMI, E. Prevalence, identification of virulence factors, O-serogroups and antibiotic resistance properties of Shiga-toxin producing Escherichia coli strains isolated from raw milk and traditional dairy products. Antimicrob. Resist. Infect. Control., v.7, p.53, 2018.

RANJBAR, R.; SEYF, A.; DEHKORDI, F.S. Prevalence of antibiotic resistance and distribution of virulence factors in the shiga toxigenic Escherichia coli recovered from hospital food. Jundishapur. J Microbiol., v.12, p.82659, 2019b.

RANJBAR, R.; YADOLLAHI FARSANI, F.; SAFARPOOR DEHKORDI, F. Antimicrobial resistance and genotyping of vacA, $\operatorname{cag} A$, and iceA alleles of the Helicobacter pylori strains isolated from traditional dairy products. J Food Safe., v.39, p.e12594, 2019a.

SAFARPOOR DEHKORDI, $\quad$ F.; AKHONDZADEHBASTI, A.; GANDOMI, H.; MISAGHI, A.; RAHIMI, E. Pathogenic staphylococcus aureus in hospital food samples; prevalence and antimicrobial resistance properties. J. Food. Saf., v.38, p.e12501, 2018.

SAFARPOOR DEHKORDI, F.; BARATI, S.; MOMTAZ, H.; HOSSEINI AHARI, S.N.; NEJAT DEHKORDI. S. Comparison of shedding, and antibiotic resistance properties of Listeria monocytogenes isolated from milk, feces, urine, and vaginal secretion of bovine, ovine, caprine, buffalo, and camel species in Iran. Jundishapur J. Microbiol., v.6, p.284-294, 2013.

SAFARPOOR, F.D.; GANDOMI, H.; BASTI, A.A.; MISAGHI, A.; RAHIMI, E. Phenotypic and genotypic characterization of antibiotic resistance of methicillinresistant Staphylococcus aureus isolated fromhospital food. Antimicrob. Res. Infect. Control., v.6, p.104, 2017.

SÁNCHEZ, G. Processing strategies to inactivatehepatitis a virus in food products: a critical review. Comp. Rev. Food. Sci. Food. Saf., v.14, p.771-784, 2015.

SEO, D.J.; LEE, M.H.; SON, N.R. et al. Seasonal and regional prevalence of norovirus, hepatitis a virus, hepatitis E Virus, and Rotavirus in shellfish harvested from South Korea. Food. Control., v.41, p.178-184, 2014. SUFFREDINI, E.; MAGNABOSCO, C.; CIVETTINI, M. et al. Norovirus contamination in different shellfish speciesharvested in the same production areas. J. Appl. Microbiol., v.113, p.686-692, 2012.

TAHK, H.; LEE, K.B.; LEE, M.H. et al. Development of reverse transcriptase polymerase chain reaction enzymelinked immunosorbent assay for the detection ofhepatitis a virus in vegetables. Food. Control., v.23, p.210-214, 2012.

VILARIÑO, M.L.; LE GUYADER, F.S.; POLO, D. et al. Assessment of human enteric viruses in cultured and wild bivalve molluscs. Int. Microbiol., v.12, p.145, 2009. 